\title{
Historic Rainfall and Record-Breaking Flooding from Hurricane Florence in the Pee Dee Watershed
}

\author{
Melissa Griffin ${ }^{1}$, Mark Malsick $^{1}$, Hope Mizzell ${ }^{1}$, and Leah Moore ${ }^{1}$
}

AUTHORS: ${ }^{1}$ SC State Climatology Office, SC Department of Natural Resources, 1000 Assembly Street Columbia, SC 29201. KEYWORDS: Florence, flooding, average return intervals, rainfall, ARI.

With the advancements of software packages and data visualization, much of the analysis and information on the impact and historical perspective of the rainfall from Tropical Storm Florence included in our online ERSI Story Map is not viable to translate into the print format standards required by many publications. However, with the newly enacted Journal of South Carolina Resources policy, our article creates a precedent in how the Journal will address submittals that include subject matter available on the internet, by permanently archiving the information, and applying a structured peer-review process to the content.

\begin{abstract}
For the third time in four years, record-breaking flooding occurred in South Carolina. Hurricane Florence, which made landfall near Wrightsville Beach, North Carolina, on September 14, 2018, moved slowly across South Carolina from September 14-17, 2018. Over those four days, heavy rain fell over portions of the Pee Dee Watershed and eastern North Carolina, with over 30 inches of rain measured by an observer in Swansboro, North Carolina. Most of the excessive rainfall was confined to the Pee Dee region, with reported totals of over 24 inches in Horry County, while closer to the Savannah River Valley observers measured less than an inch of rain. Unlike the more recent flooding events across the state, not as many rainfall records were set during this event. The amount of rainfall at various locations, and at different time intervals (1-day, 2-day, 3-day, and 4-day), had a statistical probability of occurrence of $0.1 \%$, or 1 in 1,000 chance of happening in any given year, according to the National Oceanic and Atmospheric Administration (NOAA) Atlas 14 (Bonnin et al., 2004). The rainfall associated with Hurricane Florence produced a long duration and significant flood that impacted many of the same communities still recovering from the October 2015 floods and Hurricane Matthew in 2016. Many of the rivers and streams within the Pee Dee Watershed experienced major or extreme flooding, with six stream gauges reaching record peaks, some surpassing the records set in 2016. This report provides an overview of the antecedent conditions, a synoptic summary of the event, and documentation on the meteorological and hydrological impacts observed across the Palmetto State.
\end{abstract}

\section{INTRODUCTION}

Floods are one of the most common and costly hazards in the United States. According to the National Weather Service (NWS), flood-related deaths on average are higher than fatalities from lightning or tornadoes (National Weather Service, 2016). South Carolina is vulnerable to multiple types of flooding, and flooding can occur during any month of the year in the state. Many factors can contribute to the impact of flooding caused by heavy rains, including topography and the development of land, along with antecedent conditions such as soil moisture and drought conditions.
While flooding is usually confined to the floodplain, floods can occur anywhere across the state. Areas near coastal inundation zones, streams, and rivers are more likely to experience flooding, even if they are outside of the designated 100-year floodplain. According to the Federal Emergency Management Agency's (FEMA) National Flood Insurance Program (NFIP) (Floodsmart, "Why Buy Flood Insurance?"; SCDNR, 2008), more than $20 \%$ of flood claims are made from outside of the regulated floodplain, and since 2004, FEMA and the South Carolina Flood Mitigation Program have made multiple improvements in mapping and modeling the special flood hazard area across the state. 


\section{Historic Rainfall and Record-Breaking Flooding from Hurricane Florence in Pee Dee Watershed}

\section{HYDROMETEOROLOGICAL EVOLUTION}

On May 29, 2018, the South Carolina Drought Response Committee met and voted to change the drought status of 13 counties from incipient drought conditions to normal conditions based on above-average rainfall totals, increased stream flows, and surface- and groundwater supplies. It marked the first time in two years that all 46 counties across the state were drought-free. Over the course of the summer, the combination of above-normal temperatures and below-normal rainfall across portions of the state led to the reintroduction of drought. The United States Drought Monitor started designating areas of dry conditions (D0) in much of the Midlands and Pee Dee regions, while portions of Chester, Chesterfield, Fairfield, Lancaster, and Kershaw counties reported moderate drought conditions (D1). Streamflow values across the same regions were below normal, and rivers such as the Little Pee Dee at Galivants and the Lynches at Bishopville were near record low flows. As the conditions began to warrant the potential reintroduction of drought into portions of the Pee Dee region, a statewide drought call was scheduled for Thursday, September 13, but was eventually canceled as the state began preparations for Hurricane Florence.

\section{HURRICANE FLORENCE CHRONOLOGY}

On August 30, 2018, the National Hurricane Center (NHC) designated a developing area of low pressure and disturbed weather 100 miles off the west coast of Africa as Potential Tropical Cyclone Six (PTC 6) that would eventually become Hurricane Florence. The NHC upgraded PTC 6 to a tropical depression on August 31 after it developed a welldefined circulation and cyclonically curved banding in a low shear environment. This low-shear environment supported the increased strengthening of the convection, causing NHC to quickly reclassify the depression as Tropical Storm Florence on the early morning advisory of September 1 . The storm unexpectedly, rapidly intensified into a $130-\mathrm{mph}$ hurricane over the warm mid-Atlantic surface waters on September 5, despite the southern proximity of the hurricane to an area of strong vertical shear. Florence underwent multiple cycles of weakening and rapid intensification as it moved across the Atlantic, and along with the cycles, the storm's unique track due to the position and strength of an upper-level ridge kept the entire Eastern Seaboard on edge with its approach. By September 12, Florence was centered 450 miles east-southeast of Charleston and was moving on a northwesterly course toward the Carolina coastline at 16 $\mathrm{mph}$ (Figure 1). The upper-level ridge weakened and shifted northeast of Florence on September 13, causing the storm to slow to $6 \mathrm{mph}$ and turn slowly to a more westerly course over cooler, upwelled shelf waters. Dry air entrainment weakened the eyewall complex, and aircraft reconnaissance data and coastal radar images supported an intensity downgrade to 85 knots (97 mph) on the NHC's 5:00 p.m. advisory. Despite the light, low-level shear and proximity to the deep, warm waters of the Gulf Stream, Florence's intensity changed little overnight. At 5:00 a.m. on Friday, September 14, Hurricane Florence was within 20 miles of the North Carolina coast with 90-mph winds. At 7:15 a.m., Florence made landfall near Wrightsville Beach with estimated maximum sustained winds of $90 \mathrm{mph}$ and a central pressure of $958 \mathrm{mb}$. Maximum sustained winds of $64 \mathrm{mph}$ with a gust of up to $105 \mathrm{mph}$ were recorded at the NWS Office in Wilmington. A mid-level blocking ridge across the Upper Midwest, weak steering, and frictional surface effects slowed Florence to a 3-mph crawl

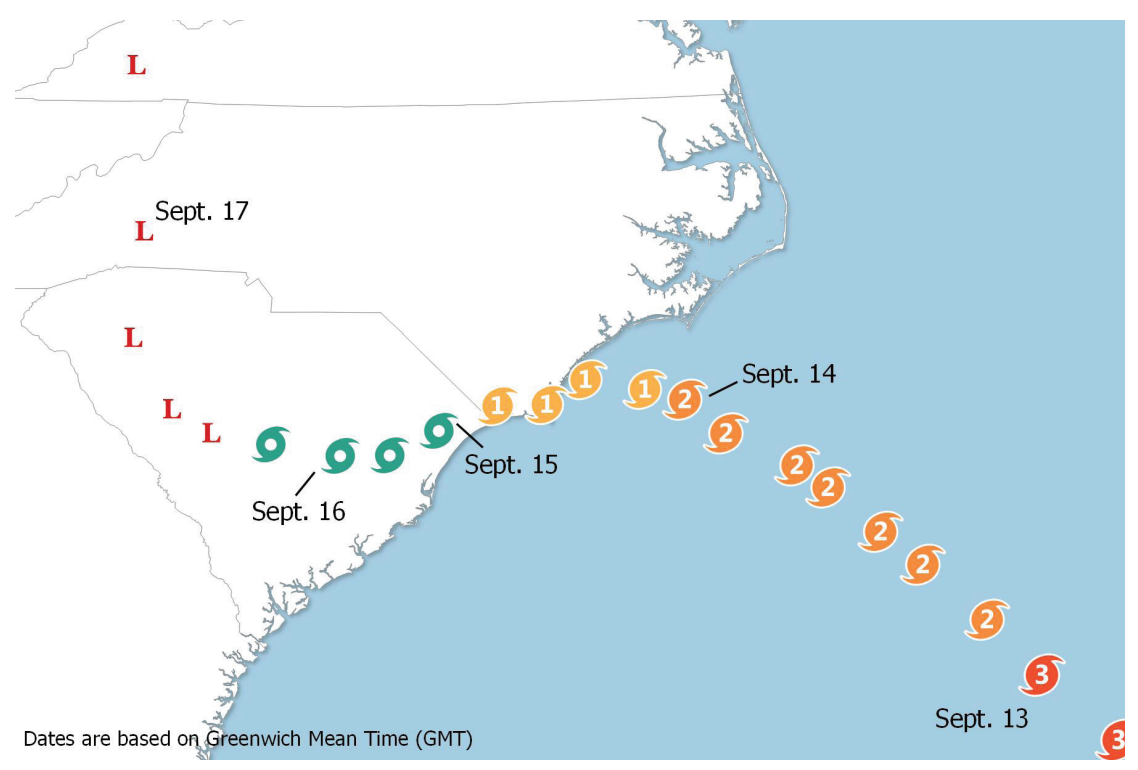

Figure 1. Track map of intensity and position of Hurricane Florence from September 13 through September 17, 2018. 
across the southern inland coast of North Carolina. Florence weakened rapidly to a tropical storm before crossing into South Carolina's Horry County at 5:00 p.m. with sustained winds of $38 \mathrm{mph}$, with occasional gusts of up to $61 \mathrm{mph}$. The storm's slow forward speed, and its wind-field expansion due to the frictional effects, kept a strong surface inflow channel locked over eastern North Carolina and the Pee Dee region of South Carolina for the next 48 hours. Florence crept slowly westward over South Carolina on September 15. As the winds continued to decay, Florence was downgraded to a tropical depression by the morning of September 16 over central South Carolina, and gradually turned to the north during the day. The remnants of Florence moved into western North Carolina by September 17, then continued to accelerate away from the region.

\section{RAINFALL ANALYSIS AND SUMMARY}

Due to the slow movement of Florence, many locations in the Pee Dee region of the state experienced 4 consecutive days of heavy precipitation. As the storm moved closer to the Carolina coast, forecast models started to predict the stall and slow progression of the system across the region. The initial quantitative precipitation forecasts (QPF) issued by the NWS the Monday before Florence made landfall suggested that rainfall totals of up to 7 inches could be seen in the South Carolina portions of the Pee Dee Watershed, with higher amounts forecasted across southeastern North Carolina. Once it was apparent the forward motion of the storm would decrease and Florence would linger over the area, the forecasted totals increased to between 10 and 20 inches for the same region (Figure 2). In total, over 30 inches of rain fell in portions of North Carolina over the 4 days of September 1417, while some locations within South Carolina approached 24 inches of rain from Florence. The highest 4-day rainfall total measured in South Carolina from Florence was 23.63 inches, from a volunteer with the Community Collaborative Rain, Hail, and Snow Network (CoCoRaHS) near Loris in Horry County. Another CoCoRaHS observer in the same area reported a 4 -day total of 23.18 inches. The 23.63-inch total reported from the CoCoRaHS station Loris 2.9 WSW was accepted by the NWS Weather Prediction Center as the record for maximum rainfall caused by a North Atlantic Tropical cyclone and their remnants for South Carolina, replacing the total of 17.45 inches from Tropical Storm Beryl in 1994 (Roth, 2018).

Figure 3 provides the average return interval (ARI) for the highest rainfall totals that fell during the 4-day event for the Loris 2.9 WSW CoCoRaHS site, using the data provided from the NOAA Atlas 14, Volume 2 (Bonnin et al., 2004). This graph illustrates the 1-day, 2-day, 3-day, and 4-day rainfall totals and their respective ARI values for the station. The observed 1-day rainfall total equates to a 100-year event, which in terms of annual exceedance probability (AEP) is equal to a $1 \%$ probability of occurring in any given year. The 3- and 4-day totals surpass the 1,000-year event (AEP of $0.1 \%$ ) at the location.

A spatial analysis comparing the observed rainfall data from Florence against the current and the ARI values was completed for the entire state. More than $8 \%$ of the state's land received a 4-day rainfall total over the 500-year ARI $(\mathrm{AEP}=.2 \%)$, most of which fell within the Pee Dee River Basin. This information was then used to compare the regions impacted by Florence with those affected during the October 2015 floods and Hurricane Matthew. Portions of Dillon, Florence, Georgetown, Horry, Marion, and Williamsburg Counties experienced their third 100-year ARI $($ AEP $=1 \%)$ event since 2015 (Figure 4). The maps in Figure 5 provide the spatial expanse of the highest rainfall totals and ARI observed during the three individual events.
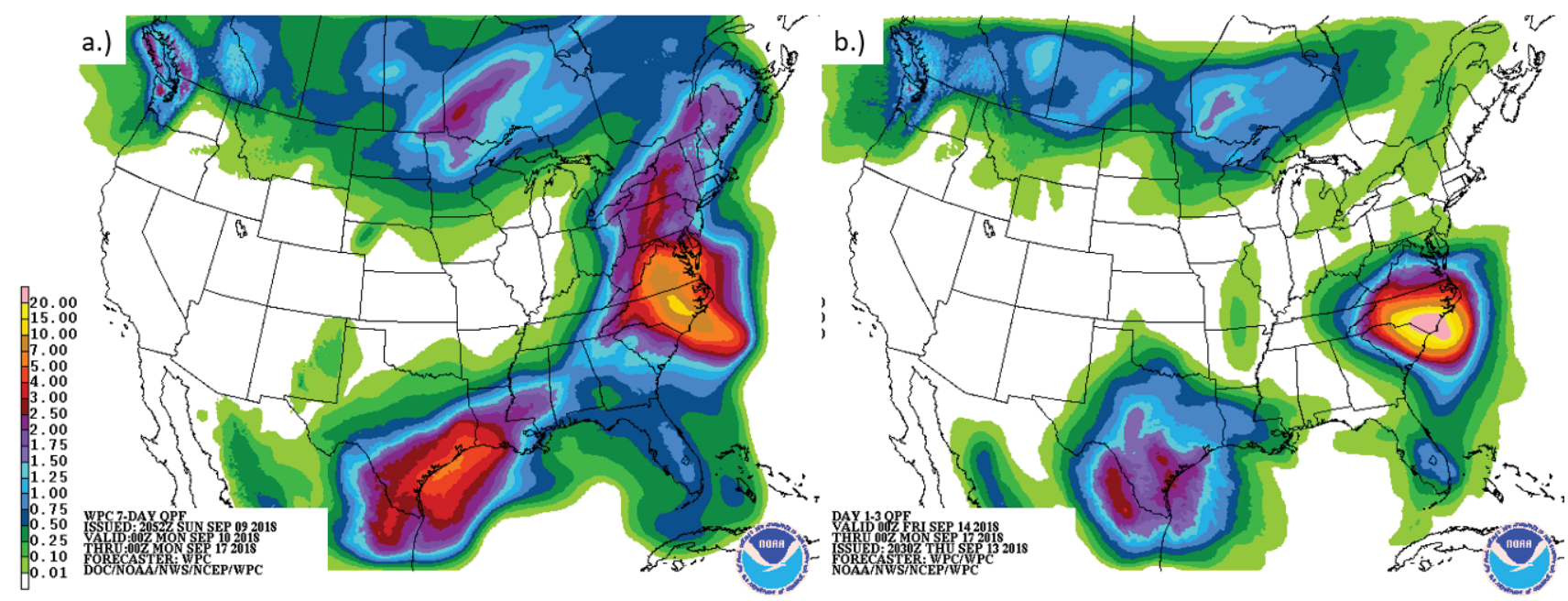

Figure 2. (a) The 7-day quantitative precipitation forecasts (QPF) issued by the National Weather Service Weather Prediction Center on September 9, 2018, and (b) the 3-day QPF totals issued on September 13, 2018. 
Historic Rainfall and Record-Breaking Flooding from Hurricane Florence in Pee Dee Watershed

\section{LORIS 2.9 WSW : HURRICANE FLORENCE: Sept $14-17,2018$}

35

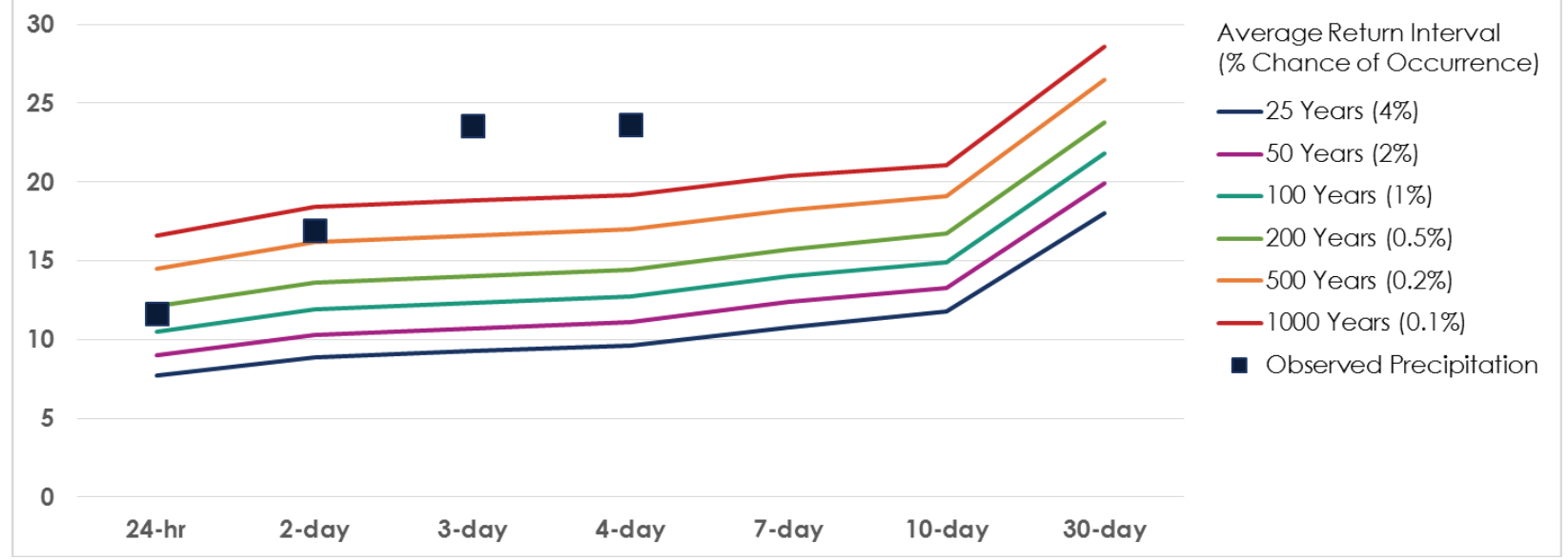

Figure 3. Average return interval (ARI) graph illustrates the average period, in years, between exceedances of the rainfall observed at the Loris 2.9 SWS CoCoRaHS station.

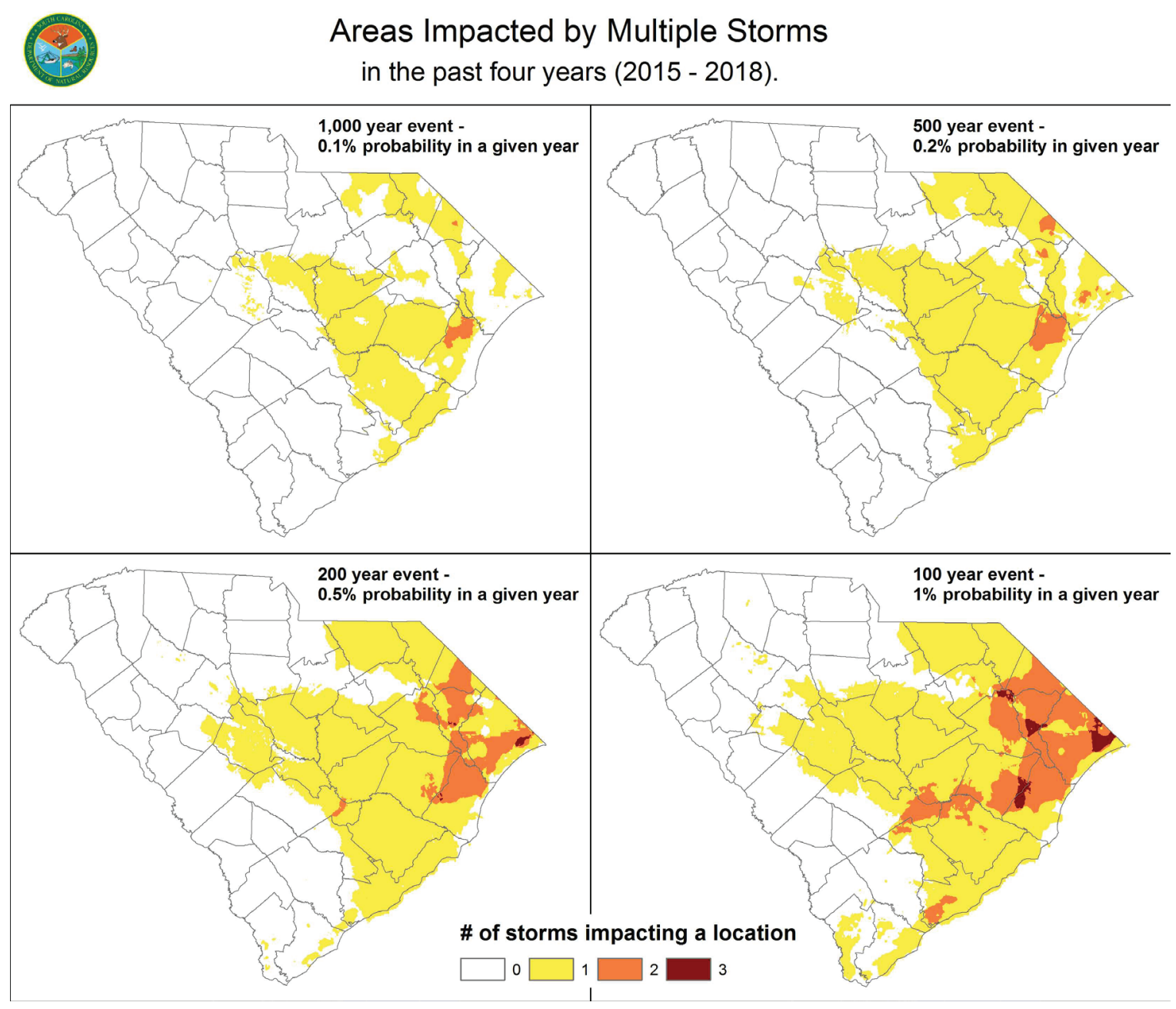

Figure 4. Overlaid average return interval (ARI) data of the observed rainfall totals from the October 2015 floods, Hurricane Matthew (2016), and Tropical Cyclone Florence (2018). Data used to create these figures was provided by MetStat, Inc. for the SC State Climate Office. 


\section{Rainfall and ARI Comparison}

(a)
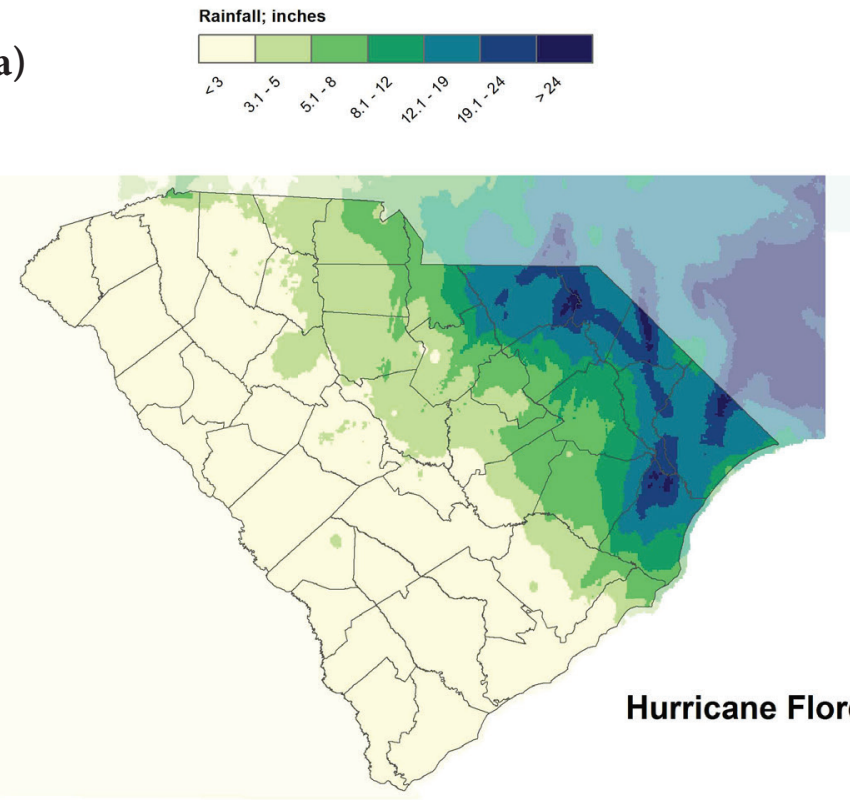

(b)

$$
\underbrace{2}
$$

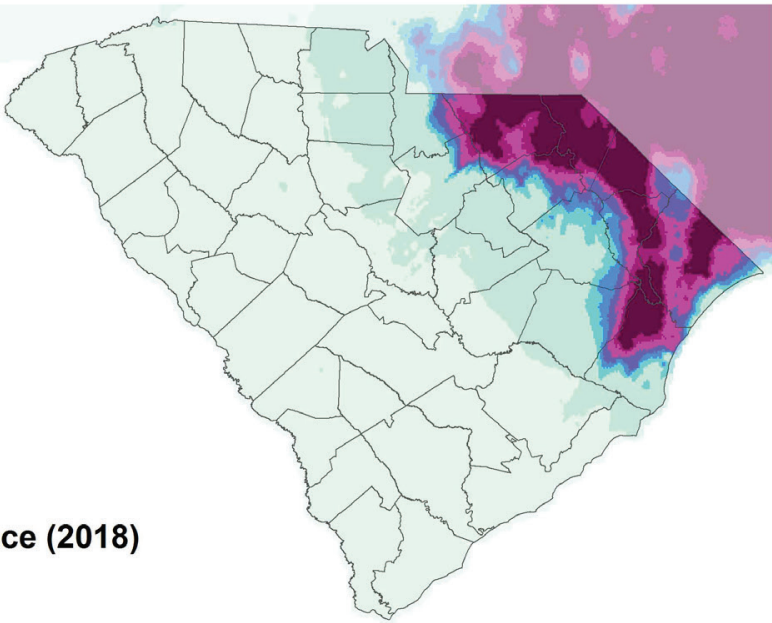

(c)

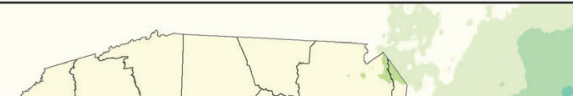

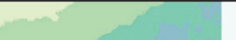
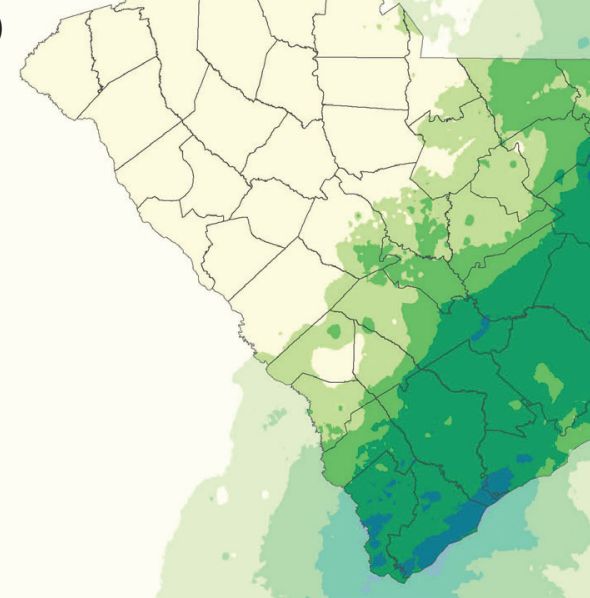

(e)

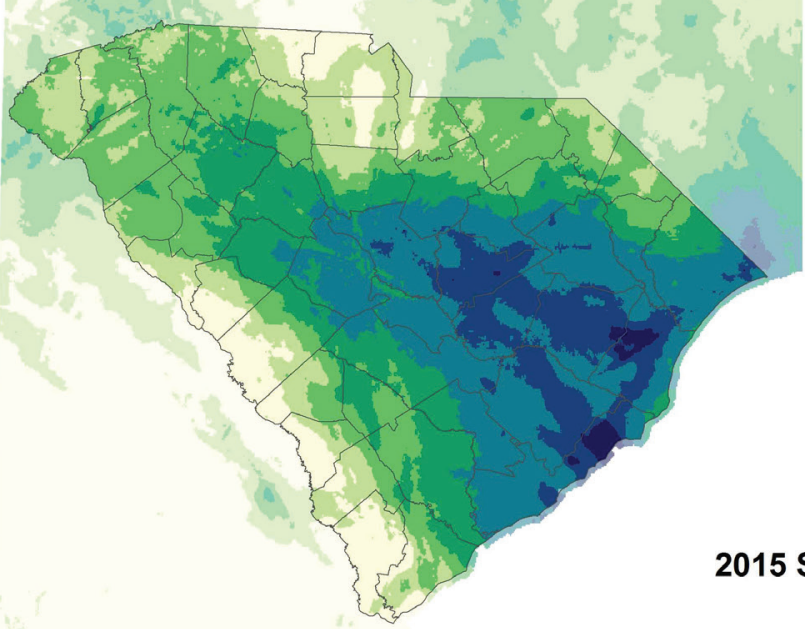

(d) \{

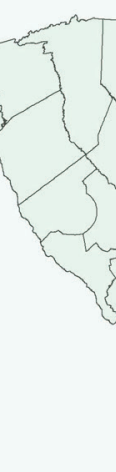

Hurricane Matthew (2016)

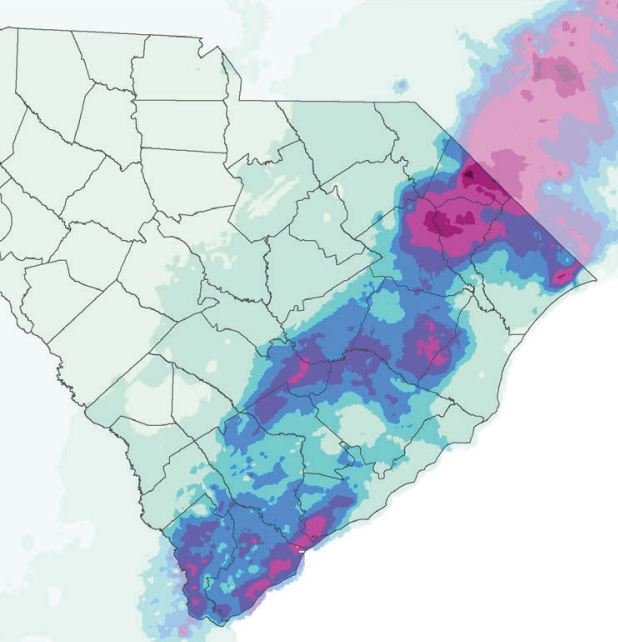

Figure 5. (a, c, e) 4-day highest rainfall totals and (b, d, f) highest average return intervals (ARI) occurring for the three separate flooding events in South Carolina: Tropical Cyclone Florence (a, b), Hurricane Matthew (c, d), and the October 2015 floods (e, f). These grids were generated by MetStat, Inc. for the SC State Climate Office, by translating observed rainfall from daily and hourly stations, with dual-pol radar precipitation estimates, into its equivalent ARI values from the NOAA Atlas 14. 


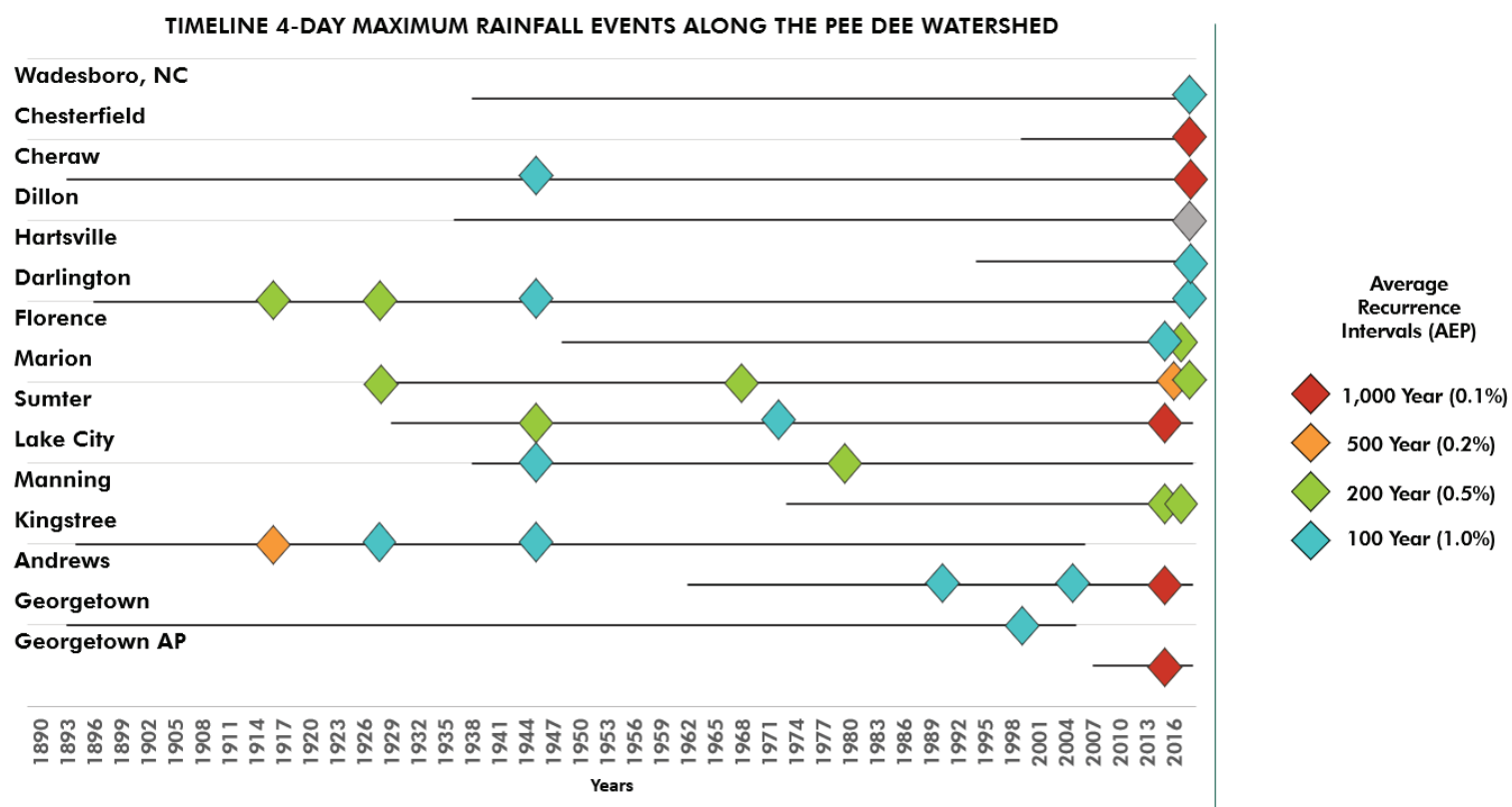

Figure 6. Timeline of the 4-day maximum rainfall events along the Pee Dee Watershed. Each line represents the period of record for an individual station, and the diamonds indicate an occurrence of maximum rainfall meeting the threshold (100-year) for the analysis. The color of the diamond represents the ARI (AEP) of the event. The gray diamond for the Dillon station indicates that while the event met or exceeded the threshold, the data did not pass quality control.

Daily precipitation data are examined from the United States Historical Climate Network (Menne and Williams, 2012) archived at the National Centers for Environmental Information (NCEI) to determine the historical perspective of the recent rainfall events located in the South Carolina portion of the Pee Dee Watershed. Stations were selected based on the length of the period of record and the percent of missing data. Time series of historical rainfall events at each station were created using the highest 1-, 2-, 3-, and 4-day rainfall events per year. A timeline graphic of the data provides a perspective of the extreme rainfall across the watershed (Figure 6).

Data from Figure 6 demonstrate that the recent rainfall observed within the South Carolina portion of the Pee Dee Watershed is unprecedented, and many locations have not experienced multiple 100-year (1\%) or higher events since 2015. At no other time in the data record has the signal been observed. Data from the timeline indicate three separate, widespread 4-day rainfall events that exceeded the 100year (1\%) and impacted the watershed before 2015: 1916, 1928, and 1945. According to river crest data provided by the Southeast River Forecast Center and the US Geological Survey (Feaster, 2018), most of the listed historic crests on rivers within the portions of the watershed, before 2015, occurred during September 1928 (Okeechobee Hurricane), September 1945 (Homestead Hurricane), and September 1999 (Hurricane Floyd), as shown in Table 1.

While these values provide a measure of the rarity for observed or forecasted rainfall and explain the likelihood of
Table 1. Table of historic crests (stage heights) across portions of the Pee Dee Watershed prior to 2015. Period of record (POR) based on the number of years ending as of 2018.

\begin{tabular}{|c|c|c|c|}
\hline \multirow[b]{2}{*}{$\begin{array}{l}\text { Gauge Location/ } \\
\text { Notes }\end{array}$} & \multicolumn{3}{|c|}{ Historical Crests Prior to 2015} \\
\hline & Stage $(\mathrm{ft})$ & $\begin{array}{c}\text { Date of } \\
\text { Occurrence }\end{array}$ & $\begin{array}{l}\text { POR (\# of } \\
\text { years) }\end{array}$ \\
\hline $\begin{array}{l}\text { Black Creek below } \\
\text { Chesterfield }\end{array}$ & 10.07 & $11 / 23 / 2006$ & 13 \\
\hline $\begin{array}{l}\text { Black Creek near } \\
\text { Quinby }\end{array}$ & 16.80 & 09/10/2004 & 17 \\
\hline $\begin{array}{l}\text { Little Pee Dee } \\
\text { River at Galivants } \\
\text { Ferry }\end{array}$ & 16.00 & $09 / 15 / 1928$ & 77 \\
\hline $\begin{array}{l}\text { Lynches River near } \\
\text { Bishopville }\end{array}$ & 22.35 & 09/19/1945 & 76 \\
\hline $\begin{array}{l}\text { Pee Dee River near } \\
\text { Bennettsville }\end{array}$ & 89.94 & $04 / 12 / 2003$ & 27 \\
\hline $\begin{array}{l}\text { Pee Dee River at } \\
\text { Pee Dee }\end{array}$ & 33.30 & 09/22/1945 & 80 \\
\hline $\begin{array}{l}\text { Pee Dee River } \\
\text { below Pee Dee }\end{array}$ & NA & NA & 22 \\
\hline $\begin{array}{l}\text { Pee Dee River } \\
\text { at Hwy } 701 \text { near } \\
\text { Bucksport }\end{array}$ & 19.54 & $04 / 12 / 2003$ & 15 \\
\hline $\begin{array}{l}\text { Waccamaw River } \\
\text { near Longs }\end{array}$ & 17.94 & 09/22/1999 & 68 \\
\hline $\begin{array}{l}\text { Waccamaw River at } \\
\text { Conway Marina }\end{array}$ & 17.64 & 09/27/1999 & 24 \\
\hline
\end{tabular}


an event, there is no one-to-one relationship between rain and flood events. Multiple factors other than rain determine the occurrence of a flood, including basin size, duration of rain, antecedent soil conditions, and land use.

\section{STREAMFLOW RECORDS}

Most of the heaviest rain occurred in North Carolina within the Yadkin-Pee Dee Watershed, which starts in the foothills of the Blue Ridge Mountains and drains through one outlet to the Atlantic Ocean, Winyah Bay in Georgetown County (Figure 7). The amount of water left behind in Florence's wake caused catastrophic flooding along the river systems within the Pee Dee Watershed, including major rivers such as the Pee Dee, Little Pee Dee, Lynches, and Waccamaw. The flooding along these blackwater rivers was not only destructive in the intensity of the rise of each river, but also in the duration of flooding that occurred. The Waccamaw River at Conway rose above major flood stage (14

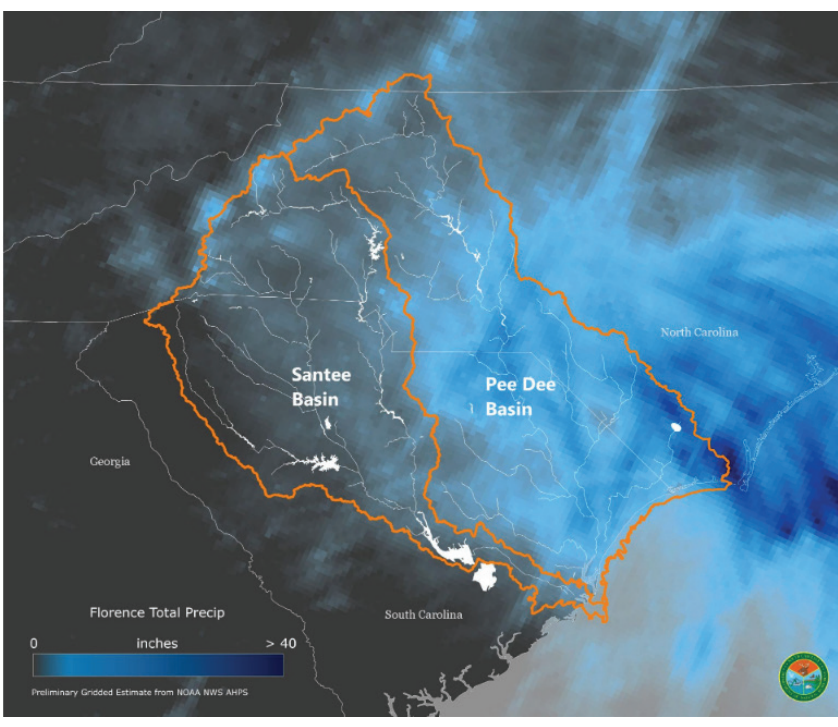

Figure 7. Map of the Yadkin-Pee Dee and Santee River Basins overlaid with quantitative precipitation estimate (QPE) data from NOAA's Advanced Hydrological Prediction Service.

Table 2. Table of US Geological Survey peak flow and peak stage data from Florence compared to historical records at the same site. Period of record (POR) based on the number of years ending as of 2018.

\begin{tabular}{|c|c|c|c|c|c|c|c|}
\hline \multirow[b]{2}{*}{$\begin{array}{l}\text { Gauge Location/ } \\
\text { Notes }\end{array}$} & \multicolumn{4}{|c|}{ Hurricane Florence Peaks } & \multicolumn{3}{|c|}{ Historical Records } \\
\hline & Stage $(\mathrm{ft})$ & Flow (cfs) & $\begin{array}{c}\text { Day } \\
\text { (September) }\end{array}$ & $\begin{array}{c}\text { Rank/ } \\
\text { POR (\# of } \\
\text { years) }\end{array}$ & Stage (ft) & Flow (cfs) & Year \\
\hline $\begin{array}{l}\text { Black Creek below } \\
\text { Chesterfield }\end{array}$ & 11.99 & 3,690 & 17 & $1 / 13$ & 10.07 & 1,480 & 2006 \\
\hline $\begin{array}{l}\text { Black Creek near } \\
\text { Quinby }\end{array}$ & 17.37 & 6,880 & 17 & $1 / 17$ & 16.81 & 6,530 & 2015 \\
\hline $\begin{array}{l}\text { Little Pee Dee River } \\
\text { at Galivants Ferry }{ }^{1}\end{array}$ & 17.21 & 66,900 & 21 & $1 / 77$ & 17.10 & 59,300 & 2016 \\
\hline $\begin{array}{l}\text { Lynches River near } \\
\text { Bishopville }\end{array}$ & 18.22 & 18,000 & 18 & $2 / 76$ & 22.35 & 29,400 & 1945 \\
\hline $\begin{array}{l}\text { Pee Dee River near } \\
\text { Bennettsville }\end{array}$ & 93.06 & 192,000 & 18 & $1 / 27$ & 89.94 & 124,000 & 2003 \\
\hline $\begin{array}{l}\text { Pee Dee River at Pee } \\
D^{2} e^{2}\end{array}$ & 31.83 & 132,000 & 21 & $2 / 80$ & 33.30 & 220,000 & 1945 \\
\hline $\begin{array}{l}\text { Pee Dee River below } \\
\text { Pee Dee }\end{array}$ & 36.96 & 139,000 & 21 & $1 / 22$ & 33.96 & 99,000 & 2003 \\
\hline $\begin{array}{l}\text { Pee Dee River } \\
\text { at Hwy } 701 \text { near } \\
\text { Bucksport }^{3}\end{array}$ & 25.00 & 136,000 & 26 & $1 / 15$ & 22.60 & 124,000 & 2016 \\
\hline $\begin{array}{l}\text { Waccamaw River } \\
\text { near Longs }\end{array}$ & 20.22 & 57,500 & 20 & $1 / 68$ & 17.94 & 28,200 & 1999 \\
\hline $\begin{array}{l}\text { Waccamaw River at } \\
\text { Conway Marina }^{4}\end{array}$ & 21.16 & 49,000 & 26 & $1 / 24$ & 17.64 & 24,100 & 1999 \\
\hline
\end{tabular}

1Based on a historical flood mark, September 2018 peak is likely the largest at this location since at least 1928.

2Streamflow regulated by six powerplants above this station.

3Regulated and tidally influenced, which is overcome by basin runoff at high flows.

4Tidally influenced, which is overcome by basin run off at high flows. 
$\mathrm{ft}$ ) on September 17, cresting at $21.16 \mathrm{ft}$ on September 26, and remained above major flood stage until October 7. The USGS peak streamflow and peak stage data for the event indicate that eight new records were set along portions of the Pee Dee River Basin, with additional stream gauges recording peaks that were the second highest on record, as presented in Table 2 (Feaster, 2018).

\section{CONCLUSIONS}

Over the course of Florence's lingering impacts on the state, emergency responders conducted 129 water rescues and over 1,000 assisted evacuations. The storm displaced nearly 8,000 people, and 233 roads were closed due to flooding. The total estimated cost of the disaster is $\$ 24$ billion (Smith et al., 2019). To most, Florence may be a memory, but many communities are faced with the hard decision of rebuilding once again. South Carolina's unique topography, its geographical location that is influenced by moisture from the Gulf of Mexico and the Atlantic Ocean, and its susceptibility to landfalling tropical systems make it possible for flooding to occur anywhere within the state. From shortterm flash flooding to the large-scale watershed flooding that occurred during Florence, these events highlight the need for improved flood modeling studies, mitigation, proactive floodplain management, and increased rainfall and streamflow monitoring.

A comprehensive interactive story map of the flooding caused by Tropical Cyclone Florence is available online at http://www.dnr.sc.gov/florence2018.

\section{ACKNOWLEDGMENTS}

Special thanks to Tanner Arrington, GIS Manager, SCDNR Land, Water and Conservation Division, for his outstanding work in creating the online interactive journal for the event.

\section{REFERENCES}

Bonnin GM, Martin D, Lin B, Parzybok T, Yekta M, Riley D. 2004/2006. Precipitation-Frequency Atlas of the United States (NOAA Atlas 14; Volume 2; Version 3). Silver Springs (MD): US Department of Commerce, National Oceanic and Atmospheric Administration, National Weather Service. http://www.nws.noaa.gov/oh/hdsc/ PF_documents/Atlas14_Volume2.pdf.

Feaster TD, Weaver JC, Gotvald AJ, Kolb KR. 2018. Preliminary peak stage and streamflow data for selected U.S. Geological Survey stream-gaging stations in North and South Carolina for flooding following Hurricane Florence, September 2018 (US Geological Survey OpenFile Report 2018-1172). Reston (VA): USGS. https://doi. org/10.3133/ofr20181172.
Floodsmart. Why Buy Flood Insurance? Federal Emergency Management Agency, National Flood Insurance Program. https://www.floodsmart.gov/why/why-buy-floodinsurance.

Griffin M. 2018. Hurricane Florence-Preliminary Open File Report. Columbia (SC): South Carolina Department of Natural Resources, South Carolina State Climatology Office. http://www.dnr.sc.gov/climate/sco/Publications/ FlorenceQuickReport_100518.pdf.

Malsick M. 2018. Hurricane Florence-Synoptic Analysis and Report (Open-File Report). Columbia (SC): South Carolina Department of Natural Resources, South Carolina State Climatology Office. http://dnr.sc.gov/ climate/sco/Publications/HurricaneFlorenceSynoptic.pdf.

Menne MJ, Williams CN JR, Vose RS. 2009. The United States Historical Climatology Network monthly temperature data, Version 2. Bulletin of the American Meteorological Society, 90:993-1007.

Menne MJ, Williams CN Jr. 2012. United States Historical Climatology Network (USHCN), Version 2.5. NOAA National Centers for Environmental Information. https:// doi.org/10.7289/V56W98B4.

NOAA. National Weather Service Southeast River Forecast Center, Historical Crest Data. https://www.weather.gov/ serfc.

NWS. JetStream-An Online School for Weather, Thunderstorm, Hazards-Flash Floods. https://www. weather.gov/jetstream/flood.

NWS. Quantitative Precipitation Forecast Archives. NOAA Weather Prediction Center. https://www.wpc.ncep.noaa. gov/archives/qpf/get_qpf_images.php.

SCDNR. 2008. Floodplain Management in South Carolina Quick Guide. Columbia (SC): South Carolina Department of Natural Resources. http://dnr.sc.gov/ water/flood/documents/SCQG_FloodplainManagement. pdf.

Roth D. 2018. National Weather Service Weather Prediction Center's Tropical Cyclone Rainfall Data. https://www.wpc. ncep.noaa.gov/tropical/rain/tcrainfall.html.

Smith A, Lott N, Houston T, Shein K, Crouch J, Enloe J. 2019. U.S. Billion-Dollar Weather and Climate Disasters 1980-2019. Asheville (NC): NOAA National Centers for Environmental Information. https://www.ncdc.noaa.gov/ billions/events.pdf. 